\title{
Centralize or Decentralize? - The Question Currently Facing Schools in Qatar
}

\author{
Al-Kubaisi Huda* \\ Qatar University, Doha, Qatar
}

\begin{abstract}
This study sought to explore the policy implementation issues related to the recent transition from an advanced EFNE decentralization to a strict re-centralization from the perspective of Qatar's school principals. It focused on understanding the advantages and disadvantages of decentralization and re-centralization to identify the most appropriate model for schools that ensures the stability of the educational policy context. Gender and total service years were also considered in the study. The data was collected from 29 principals in government schools through questionnaires. Gender and total service years were also considered. Based on this, this study reveals there to be a level of satisfaction with the current re-centralization that together with the associated accountability increases the desire to emphasize the centralized structure that previously existed. Furthermore, in terms of answering the question on whether schools should be centralized or decentralized, Qatar's current situation differs significantly from the Western concept from which it was borrowed when it was initially created. Decentralization, in some cases, is not likely to be implemented because it is simply seen of as glamorous. Therefore, it is necessary to understand the internal forces, influences, and expectations of a specific context given its cultural norms and dispositions, and the desired educational outcomes when deciding its educational future. Without evidence-based endeavors supporting any policy change proposals, it is doubtful that a practical policy implementation would succeed.
\end{abstract}

Keywords: Qatar; Education for a New Era; decentralization; recentralization; and government schools

\section{Introduction}

The contemporary worldwide movement for school reforms has introduced several initiatives aiming to decentralize the education system and increase transparency, public accountability, and community participation (Bardhan \& Mookharjee, 2006). Qatar has implemented a wide-scale reform involving

\footnotetext{
*Corresponding author: Al-Kubaisi Huda, hudaalkubaisi@yahoo.com
} 
decentralizing the schools influenced by its position as a globalized economy and its international assessment results (Cherif et al., 2012; Romanowski \& Amatullah, 2014; Alkubaisi, 2018; Romanowski \& Du, 2020). Decentralizing schooling was a core component of the 2002 top-down reform known as Education for a New Era (EFNE). Qatar lags not far behind.

EDFNE has been around for more than two decades. A quick look at the current school management reveals two approaches: theoretical and practical. One is the properly planned EFNE shift of the system (the below-explained phase) from purely centrally determined structures to advanced decentralization (2002-2016). The second is the reversal towards strictly centralization (2017 onward). A major consideration perceived behind the recent transition was the absence of a stakeholder consultation, making it problematic and complex (Abou-El-Kheir, 2017). Educational policymakers differ widely in particular contexts and tend to ignore such collaborations and influences. Other considerations that have contributed to this transition were related to economic and social issues, limited specific work procedures, and a lack of leader and teacher professional development (Nolan, 2012; Abou-El-Kheir, 2017; Romanowski \& Du, 2020). It is worth noting that decentralizing education, in a completely centralized system in nature, might also provoke resistance (ibid). It seems that these considerations and others (Nolan, 2012; Abou-El-Kheir, 2017; Romanowski \& Du, 2020) have called for re-centralizing independent schools throughout the country, including returning and renaming them 'government schools' operating under the Ministry of Education and Higher Education (MOEHE). That is to say that the degree of centralization in different countries is mostly undermined by cultural and anthropological issues (Knieling \& Othengrafen, 2016).

This study seeks to explore the current state of centralization in Qatar from a grassroots level upward. It investigates the principals' perception of documenting the implementation issues related to this transition. This is focused on understanding the advantages and disadvantages of decentralization and recentralization to find out the most appropriate model for schools that ensures the stability of the educational policy context in relation to the achievement of the schools' objectives, which are of critical importance. It also provides worthy insights into the challenges confronted when undergoing the borrowed policy implementation. Finally, studying such an issue in Arab countries is worthwhile because the decentralization and re-centralization of secondary schools and potentially primary schools is debatable.

This study addresses the following questions given the importance of understanding how and to what extent the policy is being considered:

1: What are the advantages/disadvantages of re-centralization currently being implemented in Qatar's government secondary schools?

2: What are the advantages/disadvantages of the EFNE implementation in Qatar's government secondary schools?

3: Does the participants' gender and years of experience affect their perception of the advantages/disadvantages of the EFNE policy decentralization in Qatar's government secondary schools? 
4: What is an appropriate management model to suggest for government schools?

To the best of my knowledge, there is no empirical evidence about the current state of centralization in Qatar. The only current non-empirical but conceptual analysis-based research scrutinizing this state is by Romanowski and Du. (2020). This highlighted a sharp shift from the EFNE decentralization to the current recentralization due to some of the contextual dynamics.

\section{Development of the School System in Qatar}

In the 1990s, Qatar's educational system was influenced by a traditional mindset whereby a small number of students were selected or able to pursue higher education. It was rather rigid, outdated, and resistant to reform (Brewer et al., 2007) and it was not perceived as key to economic and social progression. As Qatar transitions to a knowledge-based economy, education has mainly been intended to influence sustainable human, social, economic, and environmental development. The Rand Corporation objectively examined the system and recommended a US charter school model that decentralizes schools. With a new government-funded school structure, the Qatar system found an opportunity to improve its education system in 2002 (Brewer et al., 2007). It was claimed that this model allowed several schooling options to emerge and minimize the role of the center (Alkubaisi, 2018). Consequently, the top-down EFNE decentralization reform was driven and officially announced by the country's political leadership that had once hesitated to discuss it openly (Abou-El-Kheir, 2017). Historically, educational decentralization reforms adhere to centrally pre-defined structures and performance standards that are politically rooted (Hanson, 1998; Daun, 2005) but only successful decentralization is considered attractive and applicable (Hanson, 1998). However, whether the change was down to a political desire or was for the sake of an improvement, the national policy creation and implementation should be locally determined for a more fine-tuned educational system. Moreover, the motivation behind any decision whether to decentralize, under some contextual circumstances, should be convincing (Hanson, 1998) and related to the amount of the feature to be centralized (Petersen, 1960 as cited in Shah, 2010, 288). Generally speaking, decentralization as a globalization product (and a trend of policy change) has been diversely embraced in policy rhetoric but with precautionary measures in practice (Silova \& Eklof, 2013).

Qatar's educational map has been instituted with reforms and the necessary infrastructure to usher in decentralization. Trusting that the step-by-step transformation towards decentralization was more likely to be successful (Hanson, 1998), the gradual conversion of Ministry of Education (MOE) public schools to decentralized independent schools was regulated by the Supreme Education Council (SEC) until 2010. Authority and financial responsibility coupled with four critical principles, i.e. autonomy, accountability, variety, and choice, were also transferred to the independent schools under the supervision of the SEC to embrace decentralization and decision-making. It was strongly recommended that the central authority should continue to play a focal role in securing the policy transformation of decentralization (Hanson, 1998). As 
decentralization may take several levels of authority transformation, e.g. deconcentration, delegation, devolution, and privatization (Rondinelli et al., 1984), the form of decentralization sought by the government seems to be either delegation or devolution (Romanowski \& Du, 2020).

The EFNE is an example of a practice which diverges from its theory since all of its essential features have been slowly watered down when it is implemented through the conveyance of public education to the MOEHE, once again placing control over public schools at the central level. This evidence shows that EFNE decentralization was denied and that the earlier centralization had again been restored to the system as before (Nolan, 2012). Educational governance is often considered to measure the overall school centralization or decentralization (Brock, 2016).

Accordingly, in this study, the current state of the school management is referred to as re-centralization. In practice, many opportunities arise for policy change, formulation, accommodation, and resistance because national bureaucratic policymakers are generally distant from the sites where the policy is implemented (Jammeh, 2012). The case for decentralization is not black, white or one-sided in Qatar (Romanowski, \& Du, 2020). The reality is that when decentralization initiatives fail, it is often due to a lack of consideration placed by the political leadership rather than technical or administrative issues (Hanson, 1998).

It may be further deduced that centralization can alleviate education provision in a homogeneous context that is likely branded by shared contextual social and cultural factors, language, and religion. Accordingly, the education policy change towards decentralization is underlined by an assumption that centralization can bring about better outcomes. However, the uniqueness of a country plays an essential role in how educational systems are controlled (Rabee, 2019). Considerable local support is often fundamental for winning decentralization since it must be tied to accountability and transparency (Jeong et al., 2017).

\section{Advantages and disadvantages of school centralization and decentralization}

The advantages of centralization are, for example, that it is adopted due to its potential to make one-size-fits-all decisions and procedures rather than focusing mainly on one situation to ensure a unified and integrated management manner that is likely to resolve conflicts (Al-Ajmi, 2010). It contributes to advancing economic development because the central system modernizes institutions, increases the administrative competencies, and enhances the quality of the services provided (Weidman \& Jurand, 2012). Human capital accumulation, for instance, has been significantly accelerated by centralization (Cappelli \& Vasta, 2020). Within this, the center is responsible for educational expenses and maintaining control and compliance in the system, leading to a policy-determined performance. This is also considered appropriate when unpredictable situations are likely to arise (Marume \& Jubenkanda, 2016). Other authors have identified centralization's inability to offer good policy recommendations for economic 
development (Geo-JaJa \& Zajda, 2005; Tan, 2012) and the literature therefore offers decentralization as an alternative.

The disadvantages of centralization include how the educational policies neglect to emphasize economic diversity despite their high centralization and standardization. Rather than focusing on the effective learning process that is capable of reaching all of the students' potential, the policies strive to achieve specific targets such as the curriculum targets. It pays little attention to the specific needs of a school (Middlewiood, 2010). Investing in decentralization will give the state more management capability in the future (Orlov et al., 2020). Schools can be pressured to comply with exclusionary disciplinary policies when principals or teachers refuse to comply (Hirschfield 2010). It is also more likely that centralized systems assign teachers to schools where they are needed regardless of their preferences. This leads to less control over their working conditions (Akiba et al., 2007; Luschei et al., 2013). This affects their ability to do their job in creative, cooperative, and innovative ways in education. This may impair the school staffs' ability to do their jobs creatively, cooperatively, and innovatively (Saiti, 2013; Middlewiood, 2010). It is, however, difficult to optimally articulate the dynamics of the environment with a centralized concept due to the rigidity of this concept.

The advantages of decentralization include political control issues that can be alleviated through decentralization (Tommasi \& Weinschelbaum, 2007). The local communities would make a significant contribution to the decision-making and the level of accountability would be increased (Sharpe, 1996; Manor, 1999; Walberg et al., 2000; Zajda, 2006; Healey III \& Crouch, 2012) to promote a greater collaborative culture. It yields quicker operational decisions that perhaps allow for delays to be avoided (Gardi et al., 2020). This will likely increase the work pace, free up planning time, and boost morale and trust which will result in better work results. Decentralization facilitates policy planning by reducing excessive workloads and decision-making processes, reducing the implementation costs, and boosting the self-confidence and human resources while improving subordinate capability (Shah, 2010). Moreover, it helps to increase the capacity to pursue political objectives such as democratizing the education industry. It has proven to be advantageous for expanding engagement and participation, and getting the people involved closer to the problems (Shah, 2010). Through the creation of a better social climate, it can contribute to more meaningful jobs (Anwar \& Shukur, 2015). It is therefore creating a sense of community engagement that leads to better education as education is truly community-based. Furthermore, the active role of the leadership's professional competencies and qualifications when performing the assigned tasks is important for successful decentralization (Al-Farah, 2010; Marume \& Jubenkanda, 2016).

The disadvantages of decentralization include where centralization may create a time lag when undertaking instant actions and inflexibility. This leads to more burdened work along with a lack of responsiveness of the center (Marume \& Jubenkanda, 2016). The decentralization may be low performance on account of the subordinates' laziness or failure (Weidman \& Jurand, 2012). Coordination deficiency and different multi-level and invalid communications result in a 
disruptive and painful organizational integration (Marume \& Jubenkanda, 2016) that might surface. Leadership incapability (Al-Farah, 2015) and the resistance to sharing financial costs with the lower levels (Bray, 2003; Marume \& Jubenkanda, 2016) often hampers decentralization. Sigerson et al. (2011, p. 7) stated that principals "must feel a level of autonomy but must not be left to make all decisions alone." Hyba and Miemar (2016) affirmed that the overall degree of the cognitive, administrative, and financial delegation is fundamental. Because decentralization is based on the potential challenges of a central role and a ubiquitous state in education, the greatest challenge is the necessity for understanding the control and role of the center in planning and finance. This includes where exactly the decision-making originates from (Marume \& Jubenkanda, 2016). In Al-Mutairi's (2014) view, people in schools should be empowered and develop their leadership capabilities and skills to effectively achieve balance in management. To achieve such a balance, scholars recommend a combination of centralization and decentralization (Al-Hamad \& Al-Adwan, 2019). This is all the more true since there is no truly decentralized educational system. Most decisions have degrees of decentralization and centralization - the challenge is finding the right balance of what is critical (Hanson, 1998).

\subsection{Conceptualizing School Centralization and Decentralization}

Centralization and decentralization are widely discussed by scholars. Seemingly the opposite, they are "not paradoxical entities [... and are] two extreme[s] of the same continuum" (Shah, 2010, p.285). They are seen of as a process, not a situation (Bray, 2003) that has the potential for authoritative control (Hanson, 1998). They are important to maintaining the power and direction, and they should be wisely adopted towards education quality (Marume \& Jubenkanda, 2016). However, both notions are two sides of the same coin. To illustrate, school centralization retains the top authority as the full authority over education and related decisionmaking, control, and policies. However, it transfers the responsibility for implementation to the implementers at the lower levels from a technical viewpoint. (Shah, 2010; UNESCO, 2012; El Baradei, 2015; Marume \& Jubenkanda, 2016, Romanowiski \& Du, 2020). The literature suggests that centralization would be better when there is a lack of confidence in the individuals' competencies (Saiyed, 2009) or a lack of encouragement for entrepreneurship as well as participation among them when making decisions as a result of concentrating the policies in the center (Attia, 2009).

Decentralization, on the other hand, is where countries prefer to borrow Western ideas and acknowledge them as the potential solution to their own system-related issues. Decentralization is an instance of a non-native-born proposal that is considered a strategic choice for solving education complications (Mundy et al., 2016). Despite being a complex and political matter (Sabir et al., 2021; Winkler, 2005), it has been applauded internationally for the clear capacity to stimulate development and an individuals' greater involvement in decision-making from formulating plans to implementing them (Sabir et al., 2021; Zakari, 2012). It involves delegating responsibility and power in consideration of resource utilization and distribution by the center to the schools (Hanson, 1998; Bray, 2003; Shah, 2010; El Baradei, 2015; Marume \& Jubenkanda, 2016). This may include 
transferring decisions, policies, and allocations to the schools which enables and encourages a rapid managerial response towards solving problems, and eventually decision-making (Al-Mutairi, 2014; Martinez-Vazquez et al., 2015: Feurdean, 2020), bringing specific tasks closer to the people and pointing out where the service is to be delivered (World Bank, 2003). Through this, it builds effective decisions and benefits (Al-Saud, 2009; Al-Farah, 2015) and attains resourcefulness, creativity, and personal enhancement (Healey III \& Crouch, 2012; Bjork, 2004). Although it is more about the extent to which authority and autonomy has been delegated to the schools, it is not limited to such authorities. The advantages and disadvantages of each notion are now presented.

This is to acknowledge that I, throughout this study, consider that the disadvantages of decentralization are likely given the advantages of centralization and the disadvantages of centralization are given the advantages of decentralization.

\section{Methodology and Measures}

\subsection{Research Design and Sampling}

For the study's purpose, a quantitative descriptive rather than a qualitative research method of investigation was chosen, whereby the phenomenon is explained by collecting and then statistically analyzing the data (Aliaga \& Gunderson, 2002), building upon deductive reasoning. A quantitative approach focuses on psychological and social phenomena with a reality separate from the subjects being studied, i.e. the knower, the researcher, and the subject are viewed as relatively independent and separate (Yilmaz, 2013). This likely minimizes bias, guides towards other insights, and allows for the generalization and replication of the findings (Creswell, 2014). This study, however, was not concerned with the phenomenon in particular and instead with the perceptions of the phenomenon among the principals. In accordance with the above research questions, this study follows a design according to a structured approach used to collect and analyze data through the processes and stages described in Figure 1.

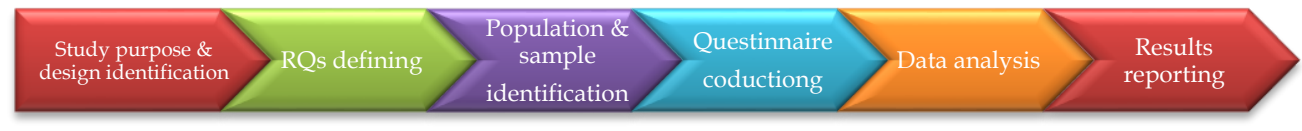

Figure 1: Research design

Since purposeful sampling provides detailed information and a thorough understanding of the people (Yilmaz, 2013), it was utilized in this study to select the principals. The only selection criterion that determined my choice of participants was that they had been principals since 2002 and were still holding the same position even after the EFNE abandonment with the hypothesis that they had lived through the EFNE decentralization (independent school principals) and have currently experienced re-centralization (government school principals). This is because I sought participants that are well-informed about the investigation, aiming to formulate predictions and generalizations (Yilmaz, 2013) to understand 
the situation of the school management. Quantitative methods require the researcher to create a pre-constructed standardized instrument or to generate categories of responses into which different perspectives and experiences fit.

The number of Qatar's secondary schools (and their principals) was 58 in the AY 2019-2020 (DEPR, 2018). Since it was challenging to estimate the exact number of the principals that met my criterion, the schools were contacted after gaining official access. In total, 42 out of 58 principals were selected as eligible which was then reduced to 29 upon return of the valid questionnaires. This study was limited to EFNE decentralization and the current re-centralization in the government schools affected by this transformation.

Furthermore, this study was limited to the state of decentralization and centralization in the case of Qatar. Only public schools were considered since they were all affected by EFNE and backsliding to centralization. The conclusions were drawn based on the perceptions of the secondary school principals during the second semester of AY 2019-2020.

\subsection{Measures}

A self-administrated, structured questionnaire was conducted online to gather responses to the above research questions between June and July 2019 (see Appendix. 1). This included the demographic variables (nationality, gender, qualification, service years) and two sections used to separately evaluate the EFNE decentralization practices and the current recentralization practices in schools (51 items). This is in addition to the centralization advantages (12 items), the centralization disadvantages (15 items), the decentralization advantages (14 items), and the decentralization disadvantages (10 items). Five responses were rated on a Likert scale ( $5=$ "very unsatisfied" to $1=$ "very satisfied"). For the Self-efficacy Questionnaire, all items were found to be statistically significant and the Cronbach's alpha coefficient for this composite scale was (0.902). Table 1 provides a brief explanation of the dimensions and the internal reliability $(>.90=$ whole questionnaire).

It is relevant to note that this study cites school principals as the most active and efficient factors in the school management.

Table 1: Validity and reliability

\begin{tabular}{|l|l|l|l|}
\hline & \multicolumn{1}{|c|}{ Dimension } & \multicolumn{1}{|c|}{ Reliability } & Validity \\
\hline 1 & The advantages of centralization. & 0.943 & 0.890 \\
\hline 2 & The disadvantages of centralization. & 0.923 & 0.852 \\
\hline 3 & The advantages of decentralization. & 0.934 & 0.874 \\
\hline 4 & The disadvantages of decentralization. & 0.933 & 0.871 \\
\hline-- & Overall total & 0.940 & 0.885 \\
\hline
\end{tabular}

\section{Data analysis}

To analyze the data, the Statistical Package for the Social Science (SPSS) and other statistics such as descriptive data, central tendency measures, means and 
variance, and standard deviations (DS) were all considered. The EFNE decentralization and current re-centralization was evaluated given that the study population estimates are represented in the calculations of the range, i.e. difference between the scale's largest and smallest values $(4 / 5=0.80)$ which also identifies the group's length. The scale's key correction standards are 1$<1.80=$ very low score, $1.80-<2.60=$ low score, $2.60-<3.40=$ average score, 3.40 $<4.20=$ high score, and $4.20-5=$ very high score. Next, the study results are presented as per the research questions.

\section{Findings}

What follows are the results of the study presented as per the research questions: 1: What are the advantages/disadvantages of re-centralization currently being implemented in Qatar's government secondary schools?

\section{Re-centralization advantages}

As shown in Table 2, strong advantages for the practices of the current recentralization are evident, in particular, "unifying policies and procedures", "increasing the ability of the principals to make timely decisions to facilitate school business," and "ensuring the absence of reduplication of decision-making mechanisms" as these items had a high mean values of 3.85 and 3.77, respectively. A high mean value for the overall total of this dimension (3.96 with an SD of 1.09) was also noted. This might reflect greater positivity among the principals, following the satisfaction of their working preferences, because the schools are controlled by the center. This brings about many benefits for leadership empowerment in particular. Thus, the re-centralization is contemplated as the most appropriate and wise option to effectively manage the schools that has been ever taken. This state is a seemingly clever education transformation. Scholars have reported that school centralization ensures the quality and reliability of forcefully determined programs, curriculum, practices, and services, the quick implementation of centrally driven changes, and achieving the effective use of human resources (Bray, 2003; Marume \& Jubenkanda, 2016). It also offers economic support for unnecessary work duplication (ibid).

Table 2: Summary of the data analysis results of the current re-centralization advantages

\begin{tabular}{|c|l|c|c|c|c|}
\hline No. & \multicolumn{1}{|c|}{ Item } & Mean & SD & Significance \\
\hline \multicolumn{5}{|c|}{ Current centralization } \\
\hline 1 & $\begin{array}{l}\text { Ensures autonomy in decision-making and } \\
\text { saves time and effort. }\end{array}$ & 3.66 & 1.09 & High \\
\hline 2 & $\begin{array}{l}\text { Increases the ability of the principal to make } \\
\text { timely decisions to facilitate the school business. }\end{array}$ & 3.77 & 1.27 & High \\
\hline 3 & $\begin{array}{l}\text { Promotes harmony among the educational } \\
\text { policies and strategies within the schools. }\end{array}$ & 3.67 & 1.09 & High \\
\hline 4 & $\begin{array}{l}\text { Allows for coordination between all aspects of } \\
\text { the education and learning process. }\end{array}$ & 3.75 & 1.22 & High \\
\hline 5 & $\begin{array}{l}\text { Aids in solving problems at a fast pace due to } \\
\text { the senior administrators' higher skills } \\
\text { compared to the junior administrators. }\end{array}$ & 3.63 & 1.04 & High \\
\hline 6 & $\begin{array}{l}\text { Allows the lower levels to be controlled and } \\
\text { accountable by the higher levels. }\end{array}$ & 3.59 & 1.47 & High \\
\hline
\end{tabular}




\begin{tabular}{|c|l|c|c|c|}
\hline 7 & $\begin{array}{l}\text { Ensures a greater commitment to the } \\
\text { regulations, policies, and procedure } \\
\text { implementation. }\end{array}$ & 3.66 & 1.09 & High \\
\hline 8 & $\begin{array}{l}\text { Ensures the absence of reduplication in the } \\
\text { decision-making mechanisms. }\end{array}$ & 3.77 & 1.27 & High \\
\hline 9 & $\begin{array}{l}\text { Determines the scope and responsibility of all } \\
\text { employees. }\end{array}$ & 3.67 & 1.09 & High \\
\hline 10 & Unifies the policies and procedures. & 3.85 & 1.12 & High \\
\hline 11 & $\begin{array}{l}\text { Unifies the job descriptions and tasks among the } \\
\text { school personnel. }\end{array}$ & 3.63 & 1.04 & High \\
\hline 12 & $\begin{array}{l}\text { Authorizes the school administration and } \\
\text { power. }\end{array}$ & 3.69 & 1.47 & High \\
\hline & Overall total & 3.96 & 1.09 & High \\
\hline
\end{tabular}

\section{Re-centralization disadvantages}

To understand the disadvantages of re-centralization in schools, Table 3 indicates that the mean and SD for the whole dimension were (2.55) and (1.51), respectively, which somewhat describes the insignificance of the perceived disadvantages of centralization. Accordingly, the participants affirmed the three managerial school-based features to be decentralized: "school responsibility for their practices, including decision-making", "school's ability to take a quick response, when needed, regarding urgent teaching and funding matters" and "human resource management and development for an appropriate school culture." It likely reflects the school community's commitment and ownership and contributes to its performance and professional development. This aligns with the conclusion reached by Al-Mutairi (2014). The participants further recognize the inability of schools to undertake strategic policies and planning which likely has an impact on the selection of competent principals (2.88 and 2.82). However, the responses to other items $(4,8$, and 12) can be considered to be fairly moderate. The sample comprehends that there is a strong tendency to take schools toward tighter centralization. The results also emphasize the strong satisfaction towards the current re-centralization as beneficial and better suited to this context.

Table 3: Summary of the data analysis results of the current re-centralization disadvantages

\begin{tabular}{|c|c|c|c|c|}
\hline No & Item & Mean & SD & Significance \\
\hline \multicolumn{5}{|c|}{ Centralization } \\
\hline 1 & $\begin{array}{l}\text { Ensures that the principals are taking full } \\
\text { responsibility and exerting a good effort. }\end{array}$ & 2.50 & 1.02 & Low \\
\hline 2 & $\begin{array}{l}\text { Relies on the principals in all matters that need to } \\
\text { be made at the school level (e.g., decisions related } \\
\text { to teaching, funds, etc.). }\end{array}$ & 2.17 & 1.03 & Low \\
\hline 3 & $\begin{array}{l}\text { Keeps the top levels of the management busy with } \\
\text { minor matters, problems, and challenges that } \\
\text { happen at the school level that could be solved by } \\
\text { the principal. }\end{array}$ & 2.73 & 1.05 & Low \\
\hline 4 & $\begin{array}{l}\text { Realizes the inability of the school principals to } \\
\text { undertake strategy-related policies, planning, } \\
\text { processes, etc. }\end{array}$ & 2.88 & 1.24 & Moderate \\
\hline
\end{tabular}




\begin{tabular}{|l|l|c|c|c|}
\hline 5 & $\begin{array}{l}\text { Realizes the incapability of the top levels of } \\
\text { management to understand/know the employees' } \\
\text { needs in the schools. }\end{array}$ & 2.59 & 1.03 & Low \\
\hline 6 & $\begin{array}{l}\text { Makes it hard to distinguish between the } \\
\text { productive/dynamic/effective and } \\
\text { destructive/apathetic/inoperative employees in } \\
\text { the schools. }\end{array}$ & 3.49 & 1.09 & Low \\
\hline 7 & $\begin{array}{l}\text { Involves adopting inaccurate perceptions that } \\
\text { could negatively affect the school performance } \\
\text { and employee evaluation. }\end{array}$ & 2.55 & 1.27 & Low \\
\hline 8 & $\begin{array}{l}\text { Leads to slowness when implementing actions, } \\
\text { events, and the provision of services that need a } \\
\text { quick decision. }\end{array}$ & .832 & 21.1 & Moderate \\
\hline 9 & $\begin{array}{l}\text { Kills innovation and creativity among the } \\
\text { principals. }\end{array}$ & 2.17 & 1.00 & Low \\
\hline 10 & $\begin{array}{l}\text { Reflects the school financing and budgeting, and } \\
\text { creates more complex and unjustified decisions. }\end{array}$ & 2.12 & 1.02 & Low \\
\hline 11 & $\begin{array}{l}\text { Prevents expertise, capability, and professional } \\
\text { development. }\end{array}$ & 2.59 & 1.06 & Low \\
\hline 12 & $\begin{array}{l}\text { Limits the ability to select more competent } \\
\text { principals for the schools. }\end{array}$ & 2.82 & 1.22 & Moderate \\
\hline 13 & $\begin{array}{l}\text { Reduces the schools' freedom and autonomy over } \\
\text { its own decisions, as well as the managerial } \\
\text { practices or activities that need to be implemented } \\
\text { that are suitable for what happens in the school. }\end{array}$ & 2.47 & 1.23 & Low \\
\hline 14 & $\begin{array}{l}\text { Reduces the sense of ownership among the } \\
\text { school's employees. }\end{array}$ & 2.51 & 1.60 & Low \\
\hline 15 & $\begin{array}{l}\text { Diminishes the flexibility and speed when } \\
\text { carrying out activities. }\end{array}$ & 2.35 & 1.32 & Low \\
\hline & Overall total & 2.55 & 1.51 & Low \\
\hline
\end{tabular}

2: What are the advantages/disadvantages of the EFNE implementation in Qatar's government secondary schools?

\section{Decentralization advantages}

As stated above, this study acknowledges the decentralization disadvantages that are the centralization advantages and vice versa, therefore research question 2 is contrary to research question 1 . Table 4 shows that the values of the mean and SD were (3.05) and (1.32) for the whole dimension, meaning that the benefits of EFNE decentralization are perceived as relatively moderate. However, the low mean values for items 2, 5, and 6, are mostly correlated to the leadership's professional development, growth, knowledge, and skills. Furthermore, various potential noticeable gains for decentralization are evidenced such as the speedy decisionmaking process (Mean $=3.97, \mathrm{SD}=1.08$ ), and communication effectiveness (Mean $=3.69, \mathrm{SD}=1.02$ ). While these examples cannot be used to determine how the principals feel about decentralization in an accurate way, they increase the mean and SD of the average value of this dimension. While my study found that decentralization allows for speedy decision-making, which is aligned with other studies (such as Abu Nasser, 2008; Saiyed, 2009; Shah, 2010; Kalalida, 2013; AlFarah, 2015), its findings concern the communications between different levels which was found to conflict with Marume and Jubenkanda's (2016). Such 
communications were perceived to be high in this study which alleviates the problem of communication overload in the system.

Table 4: Summary of the data analysis results of the EFNE decentralization advantages

\begin{tabular}{|c|c|c|c|c|}
\hline No & Item & Mean & SD & Significance \\
\hline \multicolumn{5}{|c|}{ Decentralization } \\
\hline 1 & $\begin{array}{l}\text { Promotes flexibility } \\
\text { and encourages } \\
\text { healthy competition. }\end{array}$ & 2.84 & 1.02 & Moderate \\
\hline 2 & $\begin{array}{l}\text { Allows the } \\
\text { leadership at the } \\
\text { middle level to have } \\
\text { more opportunities } \\
\text { to grow } \\
\text { professionally. }\end{array}$ & 2.17 & 0.983 & Low \\
\hline 3 & $\begin{array}{l}\text { Limits the negative } \\
\text { results of a } \\
\text { decision/action to a } \\
\text { small area/portion in } \\
\text { the school. }\end{array}$ & 3.30 & 1.06 & Moderate \\
\hline 4 & $\begin{array}{l}\text { Allows the principals } \\
\text { to demonstrate a } \\
\text { leadership style } \\
\text { suited to the } \\
\text { individuals' } \\
\text { personality. }\end{array}$ & 3.30 & 1.19 & Moderate \\
\hline 5 & $\begin{array}{l}\text { Allows the principal } \\
\text { to select employees } \\
\text { matching the } \\
\text { principal's leadership } \\
\text { vision and style. }\end{array}$ & 2.30 & 0.986 & Low \\
\hline 6 & $\begin{array}{l}\text { Motivates the school } \\
\text { employees to learn, } \\
\text { develop and compete } \\
\text { continuously. }\end{array}$ & 2.38 & 1.40 & Low \\
\hline 7 & $\begin{array}{l}\text { Allows for a speedy } \\
\text { decision-making } \\
\text { process. }\end{array}$ & 3.97 & 1.08 & High \\
\hline 8 & $\begin{array}{l}\text { Makes the } \\
\text { communications } \\
\text { flexible between the } \\
\text { school and higher } \\
\text { authority, and breaks } \\
\text { down the daily } \\
\text { routine of the school. }\end{array}$ & 3.69 & 1.02 & High \\
\hline 9 & $\begin{array}{l}\text { Attains satisfaction } \\
\text { among the } \\
\text { employees who are } \\
\text { often involved in the } \\
\text { decision-making } \\
\text { process. }\end{array}$ & 2.89 & 1.14 & Moderate \\
\hline
\end{tabular}




\begin{tabular}{|c|c|c|c|c|}
\hline 10 & $\begin{array}{l}\text { Allows for improved } \\
\text { role distribution and } \\
\text { therefore for bearing, } \\
\text { responsibility, } \\
\text { learning, and } \\
\text { expertise. }\end{array}$ & 2.86 & 1.00 & Moderate \\
\hline 11 & $\begin{array}{l}\text { Eases the burden of } \\
\text { the upper (central) } \\
\text { authorities. }\end{array}$ & 2.77 & 1.04 & Moderate \\
\hline 12 & $\begin{array}{l}\text { Speeds up the } \\
\text { process of filling in } \\
\text { vacancies in the } \\
\text { schools. }\end{array}$ & 2.81 & 1.20 & Moderate \\
\hline 13 & $\begin{array}{l}\text { Allows for the } \\
\text { discovery and } \\
\text { training of new } \\
\text { school leaders. }\end{array}$ & 3.38 & 1.30 & Moderate \\
\hline 14 & $\begin{array}{l}\text { Generates equality } \\
\text { between all } \\
\text { employees, } \\
\text { departments, and } \\
\text { authorities at all } \\
\text { levels in any } \\
\text { treatment provided. }\end{array}$ & 2.68 & 1.20 & Moderate \\
\hline & Overall total & 3.05 & 1.32 & Moderate \\
\hline
\end{tabular}

\section{Decentralization disadvantages}

In Table 5, the higher mean (3.64) indicates that the existence of many disadvantages of decentralization is characterized by a high level of inconsistency, inequality and dissimilarity regarding the decisions taken. This includes the lack of awareness of the top management over the school's business and policies and the lack of awareness of the center over the school business and policies. On many occasions, there has been a duplication of the services provided as well as a lack of integration between all departments and between the central control and accountability. Perhaps the higher mean can be partially described by the fact that most participants were exercising a new (different) situation of decentralization including the period after 2016 - aligned with the new mechanisms and regulations imposed by the MOEHE to avoid the breakthroughs experienced throughout the reform.

The low mean values for items 1 and 8 suggest that due to the late responses received from the center, schools do not make the proper decisions promptly or in a way that allows them to quickly respond to urgent issues (mean $=2.39$ and SD 1.97) as endorsed in the EFNE. A collective agreement regarding the negative impacts of decentralization on the communication channels between the departments themselves is superficial. The general impression potentially drawn from the results above is that the participants' responses seem to reflect satisfaction with the rationale underlying those impressions, suggesting that schools are satisfied with the return to centralization. Considering the tension between decentralization and centralization, we need to find regional solutions to 
collective-action problems (Lubell \& Robbins, 2022). Shah (2010) observed that it is rare to have either pure decentralization where one individual makes all the decisions or pure centralization where the decisions are made solely by the center.

Table 5: Summary of the data analysis results of the EFNE decentralization disadvantages

\begin{tabular}{|c|c|c|c|c|}
\hline No & Item & Means & SD & Significance \\
\hline & \multicolumn{4}{|l|}{ Decentralization } \\
\hline 1 & $\begin{array}{l}\text { Causes a delay in getting a response from the } \\
\text { higher authority (the Ministry) on time. }\end{array}$ & 2.39 & 1.97 & Low \\
\hline 2 & Leads to inconsistency in decisions taken. & 3.76 & 1.00 & High \\
\hline 3 & $\begin{array}{l}\text { Limits and/or weakens the power and } \\
\text { supervision in the top levels of management in } \\
\text { schools. }\end{array}$ & 3.50 & 1.68 & High \\
\hline 4 & $\begin{array}{l}\text { Weakens the implementation of school-based } \\
\text { policies and plans. }\end{array}$ & 3.54 & 1.06 & High \\
\hline 5 & $\begin{array}{l}\text { Leads to exaggerated efforts which follows on } \\
\text { bad results. }\end{array}$ & 3.57 & 1.05 & High \\
\hline 6 & $\begin{array}{l}\text { Allows for inequality in decision-making among } \\
\text { the middle leadership due to differing views. }\end{array}$ & 3.71 & 1.22 & High \\
\hline 7 & $\begin{array}{l}\text { Leads to different decisions (and therefore, } \\
\text { different results) due to the different visions of } \\
\text { the principals. }\end{array}$ & 3.79 & 1.97 & High \\
\hline 8 & $\begin{array}{l}\text { Weakens the channels of communication } \\
\text { between the department's levels in the top levels } \\
\text { of the management in schools. }\end{array}$ & 2.37 & 1.05 & Low \\
\hline 9 & $\begin{array}{l}\text { Leads to the duplication of services due to the } \\
\text { different decisions taken, therefore there is a lack } \\
\text { of integration between all departments. }\end{array}$ & 3.79 & 1.12 & High \\
\hline 10 & Lacks central control and accountability. & 3.99 & 1.18 & High \\
\hline & Overall total & 3.64 & 1.62 & High \\
\hline
\end{tabular}

3: Does the participants' gender and years of experience affect their perception of the advantages/disadvantages of the EFNE policy decentralization in Qatar's government secondary schools? How?

This question aims to identify the differences and influences of the particular characteristics of gender, qualification, and service years upon the variables. To answer this question, the means, SD, $t$-value, and one-way ANOVA (Analysis of Variance) were measured.

Gender variable: In Table 6, the significance level of both the EFNE decentralization advantages and disadvantages is less than (0.05). This highlights that no statistically significant differences exist and that the dominant perception of the EFNE decentralization is neither encouraging nor is it harmfully dependent on gender. This can be instead explained by the fact that borrowed EFNE and attached commodities like delegation, local authority, transfer...etc. are new to the school community. Because of the changes in the education landscape, these and other commodities have been introduced without enough knowledge or training provided. This poses key challenges to schools throughout Qatar. I argue 
that since such changes significantly affect the nature of work, males and females equally share the same experiences, thoughts, and perceptions about decentralization. I bear in mind that the government schools' principals are Qataris who possess an educational background, as well as being public servants. As evidenced above, feelings of satisfaction concerning the current recentralization are evident. Forms of appropriate accountability also include the increasing demand to emphasize the centrally structured system that exists and was initially desired. For me as an author, my judgment when it comes to supporting or opposing decentralization is associated with my prevailing societal cultural values which likely shapes my interpretation of the advantages/disadvantages of the EFNE decentralization.

Table 6: Summary of the data analysis results of the principals' perceptions related to EFNE decentralization by gender

\begin{tabular}{|c|c|c|c|c|c|c|}
\hline Dimension & $\begin{array}{c}\text { Variable } \\
\text { category }\end{array}$ & Means & SD & DF & T value & Sig. \\
\hline Advantage & Male. & 3.97 & 0.75 & 28 & 1.403 & 0.174 \\
\cline { 2 - 6 } & Female. & 3.27 & 0.36 & & & \\
\hline Disadvantage & Male. & 3.86 & 0.79 & 28 & 0.913 & 0.369 \\
\cline { 2 - 5 } & Female & 4.10 & 0.56 & & & \\
\hline
\end{tabular}

Studies have revealed that the leaders' culture and values influence their perception of not only the well-qualified people needed for involvement in decision-making but also the degree and scope of this involvement (Martinsons \& Davison, 2007; Ryabova, 2010). Cherif and Romanowski (2013) and Romanowski et al. (2013) found there to be a slight involvement by principals in the decisionmaking related to EFNE. The frequent policy changes and measures has also created challenging situation for the principals involved (Cherif \& Romanowski, 2013).

Table 7: Summary of the data analysis results for the principals' perceptions relate to EFNE decentralization by service year

\begin{tabular}{|l|l|c|c|c|c|c|}
\hline Dimension & $\begin{array}{l}\text { Variable } \\
\text { category }\end{array}$ & $\begin{array}{l}\text { Sum of } \\
\text { square }\end{array}$ & DF & $\begin{array}{l}\text { Mean of } \\
\text { square }\end{array}$ & $\begin{array}{l}\text { F } \\
\text { value }\end{array}$ & \multirow{2}{*}{ Sig. } \\
\hline \multirow{3}{*}{ Advantages } & Between group & .841 & 2 & .420 & \multirow{2}{*}{1.572} & \multirow{2}{*}{.227} \\
\cline { 2 - 6 } & Within group & 6.952 & 26 & .267 & & \\
\cline { 2 - 6 } & Total & 7.793 & 28 & & & \\
\hline \multirow{2}{*}{ Disadvantages } & Between group & 4.138 & 2 & 2.069 & \multirow{2}{*}{5.379} & \multirow{2}{*}{.011} \\
\cline { 2 - 5 } & Within group & 10.000 & 26 & .385 & & \\
\cline { 2 - 5 } & Total & 14.138 & 28 & & & \\
\hline
\end{tabular}

Service years: By comparing the means for the advantages and disadvantages of decentralization in Table 7, I found that despite there being no significant differences in the first, the significance level was higher than (0.5) in the latter. This includes three unequal groups. To determine which group performed better, the 'Scheffe test' was considered and the results illustrated in Table 8 indicate statistically significant differences between the groups of [' $<5$ years' and ' $5-10$ years'], and ['>10 years' and ' $<5$ years'] for the benefit of the second group in each 
(4.09 and 4.00). In fact, the EFNE journey lasted 14 years. The principals who have been in their position over the last years (2010-2015) were found to be less likely to perceive decentralization as being good. The noticeable center interventions through unjustified policy changes have influenced the degrees, processes, and procedures of school decentralization. A significant move away from school autonomy towards centrally controlled firming regulations has been felt by the sample. With this complexity, the schools understand that the transition toward centralization is surely coming up in the future. I assume that the speedy constrained moves in terms of the policy changes has sent signs to the schools indicating that there was something seriously incorrect or even wrong regarding decentralization. This has made the principals, especially those with a lengthier experience in EFNE, feel uncomfortable. Given this, the study offers important insights into how good management practices influenced by localization and expectations are dissimilarly perceived in different job phases.

Table 8: The summary of the 'Scheffe test'

\begin{tabular}{|l|l|l|l|l|l|}
\hline Dimension & Range & & $<\mathbf{5}$ yrs & $\mathbf{5}-\mathbf{1 0}$ yrs & $>\mathbf{5}$ yrs \\
\cline { 3 - 6 } Disadvantages & & Mean & 3.11 & 4.09 & 4.00 \\
\cline { 2 - 6 } & $<5$ years. & 3.11 & & $0.000^{* *}$ & $0.010^{* *}$ \\
\cline { 2 - 6 } & $5-10$ years. & 4.09 & & & 0.990 \\
\cline { 2 - 6 } & $>10$ years. & 4.00 & & & \\
\hline
\end{tabular}

4: What is an appropriate management model to suggest for government schools? The analysis of the above findings demonstrates the case of the school management that is to be proposed. This study shows that there is significant evidence in agreement with Romanowski and Du (2020). The case of EFNE decentralization likely constitutes a little more than the transfer of work (but not power) from MOEHE to the schools. This reminds us of what Arnove (2005, p. 434) stated: "an English colleague quipped to me what decentralisation meant in Britain: "centralization of control, and decentralization of responsibility," roughly corresponding to Hanson's definition of "deconcentration"." In this context, regardless of whether the transition towards de-concentration was opted for or accidentally resulted from the sudden sharp return to centralization, it is more relevant to the interests of the political/higher leadership - rather than a decentralization approach - with greater administrative gains that are concerned only with maximizing resource utilization (Turner, 2002). In this sense, this study aimed to determine a management model deemed appropriate and fit for the schools based on the theoretical discussion and assessment of the data analysis. I assume that this model is unique and evolved using the following themes:

A management-oriented approach that represents a merger management model combining the advantages of current re-centralization and EFNE decentralization has been put into one single framework. My proposed model echoes the call of many scholars to ensure a blended management model (e.g. Al-Hamad \& AlAdwan, 2019). It builds upon the vision of the education system and the human development pillar in QNV 2030. Features such as the identification, selection, recruitment, firing, and rewarding of potential schoolteachers and employees 
would be centralized within the MOEHE structure. Full responsibility for schoolbased decisions, financial issues, and more opportunities related to the professional development should be decentralized within the school. Within this approach, determining more operational and instructional freedom and greater choice over the teaching strategies and approaches and learning activities in schools towards the achievement of objectives is crucial. This creates considerable success and guarantees the enjoyment of learning.

Although the development of important control issues, ranging from the curriculum and assessment to salaries and benefits is essential, these issues should be centrally determined. Decentralization policies should not affect curricular programs, standardization, assessments, salaries, and benefits. The power and authority and the financial resources and allocations decentralized to schools demands appropriate control through accountability procedures. Enforcing greater accountability and efficiency is a hallmark of globalization. This brings in a greater degree of control in terms of the effectiveness and accountability into the core of the model, likely providing the basis for a stable policy context. .

A fundamental structural feature is the construction of a clear regulatory framework that formally segregates the powers and decisions delegated to schools from the MOEHE business. This not only avoids conflicts of interest between both structures but also provides opportunities for schools to act clearly and autonomously. This creates the potential for the MOEHE to ensure quality by understanding when and what to centralize, and also when and what not to decentralize, on both a technical and ethical basis.

Considering that Qatar is administratively divided into ten municipalities and then into smaller zones, it is better to geographically distribute schools to the zone/municipality to which they belong. Phrased differently, multiple educational management bodies operating under the supervision of MOEHE should be formed. This allows for the retaining of most of the control and responsibility for planning, legislations, and laws, financing, and development. This will help to better meet the school's expectations since "the actual form of decentralization varies significantly from country to country and even from school to school in the same town, depending on a variety of factors" (Arnove, 2005, p. 583).

A preliminary well-designed ingenious implementation plan must be considered and tested for at least three years beforehand. It aims to identify (and likely solve) the challenges and opportunities that might emerge before being permanently anchored in the system. Schools must guarantee further opportunities and the voices and authorities have to make significant changes within the regulatory framework to meet any anticipated or potential challenges or obstacles when implementing this model.

\section{Concluding remarks}

Like most educational reforms, a careful observation of the findings has shown that market forces, the obligations of the local context, and cultural factors have shaped the school management in Qatar. It was assumed that by achieving school 
decentralization, the competition would greatly reinforce its market-driven premise and promote the academic achievements of schools to obtain more students. Although research claims that measuring the willingness of lower entities before decentralizing is important (Hanson, 1998), marketization and neoliberal inspirations were found to be hindered by the local context and perhaps more centrally imposed regulations when it comes to policy change and implementation.

The difficulties in the EFNE decentralization scenery have resulted, as voiced by Romanowski and Du (2020), in more de-concentration than delegation. Deconcentration involves the transfer of work and tasks but not necessarily a transfer of authority and power (Hanson, 1998; El Baradei, 2015). Put together to answer a question on whether schools should be centralized or decentralized, Qatar's current situation differs significantly from the Western concept from which it was borrowed when it was initially created. Decentralization, in some cases, is not likely to be implemented because it is simply seen of as glamorous. Therefore, it is necessary to understand the internal forces, influences, and expectations of a specific context given its cultural norms and dispositions and the desired educational outcomes when deciding its educational future. Without evidence-based endeavors supporting any of the policy change proposals, it is doubtful that a practical policy implementation would succeed. It is true that neoliberalism has influenced educational policies both positively and inappropriately but its knowledge interpretation is not as anticipated (Zajda, 2005). As Turner (2005, p. 91) states, there are not yet any "multi-centered theories" that would help us to understand centralization and decentralization. This includes whether borrowed autonomy was practiced and whether centralization and decentralization were fully understood. Without evidence-based endeavors supporting any policy change proposals, it is doubtful that a practical policy implementation would succeed.

\section{Conflict of Interest}

No potential conflict of interest was reported by the authors concerning the research, authorship, and/or publication of this article.

\section{Funding}

The author(s) received no financial support for the research, authorship, and/or publication of this article.

\section{References}

Al-Ajmi, M. (2010). Educational Administration and Planning. Amman, Jordan: Al Masirah House for Publishing and Distribution.

Al-Farah, W. (2010). Administration Issues in the educational, school, and formal administration. Amman, Jordan: Al-Warraq Institution for Publishing and Distribution.

Al-Farah, Y.F. (2015). Concepts of centralisation and administrative decentralisation. Gedaref, Sudan: Gedaref University.

Al-Hamad, B.M., \& Al-Adwan, R. (2019). Balancing centralisation and decentralisation management at the University of Bahrain. Quality Assurance in Education, 27(2), 237-250. 
Al-Mutairi, R.M. (2014). The degree of central and decentralised administration application in educational areas in the State of Kuwait from the viewpoint of school principals [Master's thesis]. Middle East University, Amman. http://0search.mandumah.com.mylibrary.qu.edu.qa/Record/722617

Al-Saud, S. (2009). Educational administration: Concepts and prospects. Muscat, Oman: Tariq \& Partners Company.

Abu Nasser, F. (2008). Introduction to Educational Administration. Amman, Jordan: Al Masirah House for Publishing and Distribution.

Akiba, M., LeTendre, G. K., \& Scribner, J. P. (2007). Teacher quality, opportunity gap, and national achievement in 46 countries. Educational researcher, 36(7), 369-387.

Aliaga, M. \& Gunderson, B. (2002). Interactive Statistics. Harlow and Upper Saddle River, NJ: Pearson Education.

Alkubaisi, H. (2018). Decentralised Management in Independent Secondary Schools in Qatar's Educational Reform Initiative (Unpublished doctoral dissertation). UCL Institute of Education, UCL, United Kingdom.

Anwar, G., \& Shukur, I. (2015). The Impact of Service Quality Dimensions on Students' Satisfaction. International Journal of Social Sciences \& Educational Studies, 76.

Arnove, R. (2005). Globalisation and public education policies in Latin America: Challenges to and contributions of teachers and higher education institutions. In M. Geo-Jaja \& J. Zajda (Ed.), An International Handbook on Globalisation, Education and Policy Research (pp.405-430). The Netherlands, Dordrecht, The Netherlands: Springer.

Bardhan, P. \& Mookharjee, D. (2006). Decentralisation and accountability in infrastructure delivery in developing countries, The Economic Journal, 116, 101 - 127.

Bray, M. (2003). Control of Education: Issues and tensions in centralisation and decentralisation. In R. F. Arnove and C. A. Torres (Eds.), Comparative education: The dialectic of the global and the local (2nd ed.). Lanham, MD: Rowman \& Littlefeld.

Brewer, D., Goldman, C., Augustine, C., Zellman, G., Ryan, G., Stasz, C., \& Constant, L. (2006). An introduction to Qatar's primary and secondary education reform. Santa Monica, CA: RAND Education. https://www.rand.org/content/dam/rand/pubs/working_papers/2006/RAN D_WR399.pdf

Brewer, D.J., Augustine, C.H., Zellman, G.L., Ryan, G.W., Goldman, C.A., Stasz, C., \& Constant, L. (2007). Education for a new era: Design and implementation of K-12 education reform in Qatar. Santa Monica, CA: RAND Education. http://www.rand.org/pubs/mono- graphs/MG548

Brock, C. (2016). Geography of education: scale, space and location in the study of education. Bloomsbury Publishing.

Cappelli, G., \& Vasta, M. (2020). Can school centralization foster human capital accumulation? A quasi-experiment from early twentieth-century Italy. The Economic History Review, 73(1), 159-184.

Cherif, M. \& Romanowski, M. (2013). Education for a new era: Stakeholders' perception of Qatari educational reform. International Journal of Education Policy and Leadership, 8 (6), 1-17.

Creswell, J.W. (2014). Research design: Qualitative, quantitative, and mixed methods approaches. ( $4^{\text {th }}$ ed.). Thousand Oaks, CA: Sage Publications, Inc.

Daun, H. (2005). Globalisation and the governance of national education systems. In J. Zajda (Ed.), An International handbook on globalisation, education and policy research (pp. 93-108). Cham, Switzerland: Springer.

DEPR. (2018). Statistical Bulletin of education: Bulletin May 2018. Ministry of Education and Higher

Education,

Doha. 
http://www.edu.gov.qa/Ar/structure/deputy/MonthlytStatisticsIssues/Broch ure\%20ver2\%20May\%202018.pdf

Feurdean, C.C. (2020). Decentralization of Primary and Secondary Education-Emergency during the Pandemic. JL \& Admin. Sci., 14, 57.

Gardi, B. (2021). The effects of computerized accounting system on auditing process: a case study from northern Iraq. Available at SSRN 3838327

Geo-JaJa, M. \& Zajda. J. (2005). Rethinking Globalisation and the Future Role of Education in Africa. In J. Zajda (Ed.), An International handbook on globalisation, education and policy research. Cham, Switzerland: Springer.

Hanson, M. E. (1998). Strategies of educational decentralisation: Key questions and core issues. Journal of Educational Administration, 36(2), 111-128.

Healey III, F. H., \& Crouch, L. (2012). Decentralization for High-Quality Education: Elements and Issues of Design. RTI Research Report Series. Occasional Paper. RTI International.

Hirschfield, P.J. (2010). School Surveillance in America: Disparate and Unequal. Pp. 28-54 in Schools under Surveillance: Cultures of Control in Public Education, edited by Torin Monahan and Rodolfo Torres. New Brunswick, NJ: Rutgers University Press.

Hyba, Z. M., \& Miemar, S. (2016). The requirements for a shift towards decentralisation in public education in the Kingdom of Saudi Arabia. The Arab Gulf Letter: Arab Bureau of Education for the Gulf States, 37(142), 35-53.

Jeong, D. W., Lee, H. J., \& Cho, S. K. (2017). Education decentralization, school resources, and student outcomes in Korea. International Journal of Educational Development, 53, 12-27.

Kalalida, D. (2013). Recent trends in educational leadership. Amman, Jordan: Zahran Publishing and Distribution House.

Knieling, J., \& Othengrafen, H. (2016). (Eds.). Planning Culture in Europe, vol. 2016, Routledge, New York, pp. 39-62.

Lubell, M., \& Robbins, M. (2022). Adapting to Sea-Level Rise: Centralization or Decentralization in Polycentric Governance Systems?. Policy Studies Journal, 50(1), 143-175.

Luschei, T., Chudgar, A., \& Rew, W.J. (2013). Exploring differences in the distribution of teacher qualifications across Mexico and South Korea: Evidence from the Teaching and Learning International Survey. Teachers College Record, 115(5).

Martinez-Vazquez, J., Lago-Peñas, S., Sacchi, A., (2015). The Impact of Fiscal Decentralization: A Survey (No. 1505). Universidade de Vigo, GEN-Governance and Economics research Network.

Martinsons, M.G. \& Davison, R.M. (2007). Strategic decision-making and support systems: comparing American, Japanese and Chinese management. Decision Support Systems 43(1), 284-300.

Marume, S., \& Jubenkanda, R. (2016). Centralization and Decentralization. Journal of Research in Humanities and Social Science, 4(6), 106-210

Ministry of Development Planning and Statistics. (2008). Qatar National Vision 2030. Doha, Qatar: General Secretariat for Development Planning and Statistics. http://www.mdps.gov.qa/en/qnv/Documents/QNV2030_English_v2.pdf

Mundy, K., Green, A., Lingard, B., \& Verger, A. (Eds.). (2016). Handbook of global education policy. Sussex, United Kingdom: John Wiley \& Sons Ltd.

Nolan, L. (2012). Liberalising Monarchies? How Gulf Monarchies Manage Education Reform. Brookings. https://www.brookings.edu/research/liberalizing-monarchieshow-gulf-monarchiesmanage-education-reform/ 
Orlov, V., Khamidov, O., Poliakova, V., \& Shylova, V. (2020). The Problem of Decentralization of Public Power in the Context of Territorial's Independence. In III International Scientific Congress Society of Ambient Intelligence Advances in Economics, Business and Management Research, 129, 370-377.

Qatar General Secretariat for Development Planning. (2015). Annual statistical abstract. Doha, Qatar: Planning Council Publications.

Qatar General Secretariat for Development Planning. (2008). Qatar National Vision 2030. Doha, Qatar: Planning Council Publications.

Rabee, A.M. (2019). Requirements and Role of Increasing the Decentralization of Education Management under Good Governance - The Hashemite Kingdom of Jordan. Multi-Knowledge Electronic Comprehensive Journal For Education And Science Publications (MECSJ ), 19, 2616-9185.

Romanowski, M.H., Cherif, M., Al Ammari, B. \& Al Attiyah, A. (2013). Qatar's Educational Reform: The Experiences and Perceptions of Principals, Teachers and Parents. International Journal of Education, 5, (3), 119-146.

Romanowski, M.H., \& Amatullah, T. (2014). The impact of Qatar national professional standards: Teachers' perspectives. International Journal of Research Studies in Education, 3(2), 97-114.

Romanowski, M.H., \& Du, X. (2020). Education transferring and decentralized reforms: The case of Qatar. Prospects, 1-14.

Rondinelli, D.A. et al. (1984). Decentralisation in Developing Countries: A Review of Recent Experiences. Staff Working Paper No. 581. Washington, D.C.: World Bank.

Ryabova, G. (2010). Cross-cultural differences in decision-making styles of Thai and foreign principals in Thai and international schools in Bangkok. Scholar 2(1) 30 34.

Sabir, B. Y., Jabbar Othman, B., Gardi, B., Burhan Ismael, N., Abdalla Hamza, P., Sorguli, S., ... \& Anwar, G. (2021). Administrative Decentralization: The Transfer of Competency from The Ministry of Education to General Directorates. International Journal of Rural Development, Environment and Health Research (IJREH), 5.

Saiti, A. (2013). Reforms in Greek education 1991-2011: Reforms or something else? eJournal of Education Policy. http://nau.edu/COE/eJournal/_Forms/spring2013/Saiti. (online 10 pages):

Saiyed, O. (2009). Between the central educational administration and decentralisation. City of publication, Egypt: Science and faith for publication and distribution.

Shah, J.I. (2010). Centralisation versus Decentralisation in Education. Dialogue, 5(3), 18196462.

Sigerson, T. Ames, K., Levey, E., Murphy, M., Morote, E.S., \& Inserra, A. (2011). Principal autonomy: How it relates to academic achievement and superintendent leadership responsibilities.https://www.scopeonline.us/wpcontent/uploads/2017/10/LIER-Spring-2012.pdf

Silova, I., \& Eklof, B. (2013). Education in Eastern and Central Europe: Re-thinking postsocialism in the context of globalization. In F. Arnove, C. Torres, \& S. Franz (Ed.), Comparative education: The dialectic of the global and the local (pp. 379-402). Plymouth, United Kingdom: Rowman \& Littlefield.

Tommasi, M., \& Weinschelbaum, F. (2007). Centralization vs. decentralization: A principal-agent analysis. Journal of public economic theory, 9(2), 369-389.

Turner, M. (2002). Whatever happened to de-concentration? Recent initiatives in Cambodia. Public Administration and Development: The International Journal of Management Research and Practice, 22(4), 353-364.

UNESCO. (2012). Decentralisation in Education: National Policies and Practices. Paris, France: Division of Educational Policies and Strategies, UNESCO. 
Weidman, J., \& Jurand, R. (2012). EQUIP2 State-of-the-Art Knowledge in Education: Decentralisation, A Guide to Education Project Design Based on a Comprehensive Literature and Project Review. United States Agency for International Development (USAID).

https://www.researchgate.net/profile/John_Weidman/publication/280447334 _EQUIP2_State-of-the-

Art_Knowledge_in_Education_Decentralization/links/55b5a98508aed621de02e 618.pdf

Winkler, D.R. (2005). Understanding Decentralisation. USAID. www.equip123.net/docs/e2Understanding\%20Decentralization.pdf

World Bank. (2008). MENA Development Report: The Road Not Traveled Education Reform in the Middle East and North Africa. Washington, DC: World Bank.

Yilmaz, K. (2013). Comparison of quantitative and qualitative research traditions: Epistemological, theoretical, and methodological differences. European journal of education, 48(2), 311-325.

Zajda. J. (2005). Globalisation, education and policy research: Overview and introduction. In J. Zajda (Ed.), An International handbook on globalisation, education and policy research. Cham, Switzerland: Springer.

Zellman, G.L., Ryan, G.W., Karam, R., Constant, L., Salem, H., Gonzalez, G., Orr, N., AlThani, H., \& Al-Obaidli, K. (2009). Implementation of the K-12 education reform in Qatar's schools. Santa Monica, CA: RAND Education. http://www.rand.org/content/dam/rand/pubs/monographs/2009/RAND_ MG880.pdf

Zellman, G.L., Constant, L. \& Goldman, C.A. (2011). K-12 education reform in Qatar. Santa Monica, CA: RAND Education. 


\section{Appendix 1: The research questionnaire}

Dear principal,

I am conducting a survey questionnaire to gather data for a research project titled "Centralize or decentralize? - The question currently facing schools in Qatar". This research aims at understanding the advantage and the disadvantages of ENER decentralization and current re-centralization to find out the appropriate model for schools that ensures the stability of the educational policy context. It also seeks the exploration of the policy implementation issues related to the recent transition from an advanced decentralization to a strict re-centralization from the perspective of Qatar's school principals. Therefore, I would like to draw upon your expertise through your participation in this survey.

Your response is voluntary and it may take 15 minutes of your time to complete this questionnaire. You can withdraw at any time or skip any question you like.

Again, your completion of the questionnaire is critical and important to my research and our understanding of the topic. The confidentially and your anonymity is guaranteed. A summary of findings will be provided to participant on request and If you have any question, you may contact any one of the below mentioned researchers.

Thank you in advance for your participation.

Dr Huda Alkubaisi

Assistant professor of Education Finance

Educational Science Dept., College of Education

Qatar University

huda@qu.edu.qa

Office phone no: 44-03-5196

$\square$ I acknowledge that I have read, understand, and agree to participate

Participant signature Researcher signature 


\section{Respondent demographics}

The following questions relate to your background, and experience.

\section{1) Respondent Characteristics}

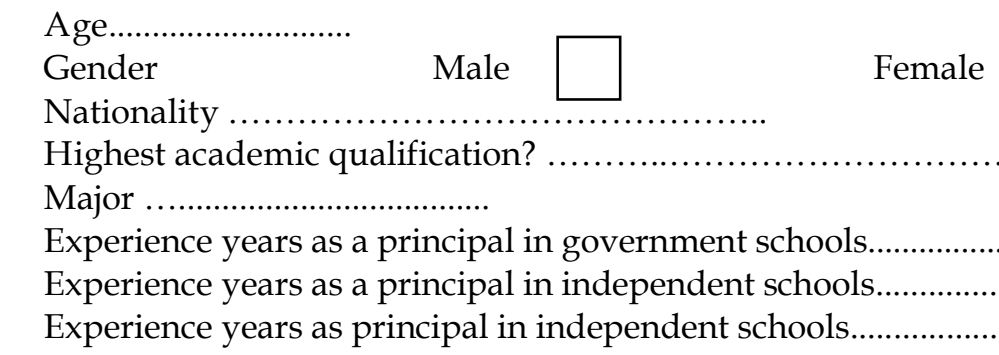

\section{Section II:}

In this section, the following statements are designed to obtain your perceptions and understanding of the advantage and the disadvantages of ENER decentralization and current re-centralization in four domains. To participate in the study, the researcher needs your cooperation by answering the questionnaire statements accurately, honestly and objectively. These statements can be answered by selecting and ticking the most appropriate choice that best describes your answers/thoughts.

Please answer ALL the following statements. If an item/a statement is irrelevant, or if you are unsure or do not know the answer, feel free to leave the answer blank.

\begin{tabular}{|c|c|c|c|c|c|c|}
\hline S. & Item & $\begin{array}{c}\text { Very } \\
\text { unsatisfied }\end{array}$ & Unsatisfied & Neutral & Satisfied & $\begin{array}{c}\text { Very } \\
\text { satisfied }\end{array}$ \\
\hline \multicolumn{7}{|c|}{ Current re-centralization advantages } \\
\hline 1 & $\begin{array}{l}\text { Ensures autonomy in decision- } \\
\text { making and saves time and effort. }\end{array}$ & & & & & \\
\hline 2 & $\begin{array}{l}\text { Increases the ability of the principal } \\
\text { to make timely decisions to facilitate } \\
\text { the school business. }\end{array}$ & & & & & \\
\hline 3 & $\begin{array}{l}\text { Promotes harmony among the } \\
\text { educational policies and strategies } \\
\text { within the schools. }\end{array}$ & & & & & \\
\hline 4 & $\begin{array}{l}\text { Allows for coordination between all } \\
\text { aspects of the education and learning } \\
\text { process. }\end{array}$ & & & & & \\
\hline 5 & $\begin{array}{l}\text { Aids in solving problems at a fast } \\
\text { pace due to the senior administrators' } \\
\text { higher skills compared to the junior } \\
\text { administrators. }\end{array}$ & & & & & \\
\hline 6 & $\begin{array}{l}\text { Allows the lower levels to be } \\
\text { controlled and accountable by the } \\
\text { higher levels. }\end{array}$ & & & & & \\
\hline 7 & $\begin{array}{l}\text { Ensures a greater commitment to the } \\
\text { regulations, policies, and procedure } \\
\text { implementation. }\end{array}$ & & & & & \\
\hline 8 & $\begin{array}{l}\text { Ensures the absence of reduplication } \\
\text { in the decision-making mechanisms. }\end{array}$ & & & & & \\
\hline 9 & $\begin{array}{l}\text { Determines the scope and } \\
\text { responsibility of all employees. }\end{array}$ & & & & & \\
\hline 10 & Unifies the policies and procedures. & & & & & \\
\hline 11 & $\begin{array}{l}\text { Unifies the job descriptions and tasks } \\
\text { among the school personnel. }\end{array}$ & & & & & \\
\hline 12 & $\begin{array}{l}\text { Authorizes the school administration } \\
\text { and power. }\end{array}$ & & & & & \\
\hline
\end{tabular}




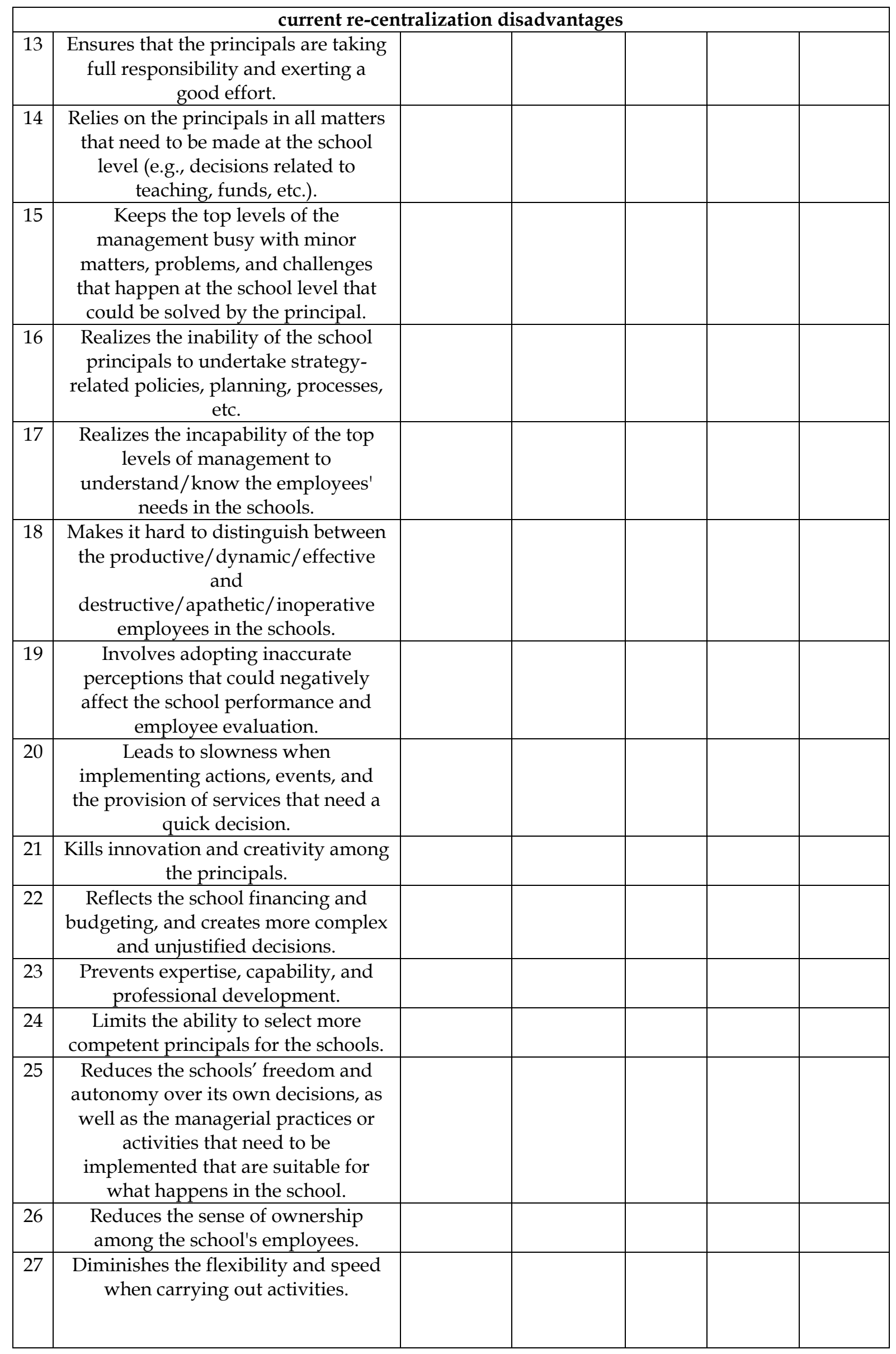




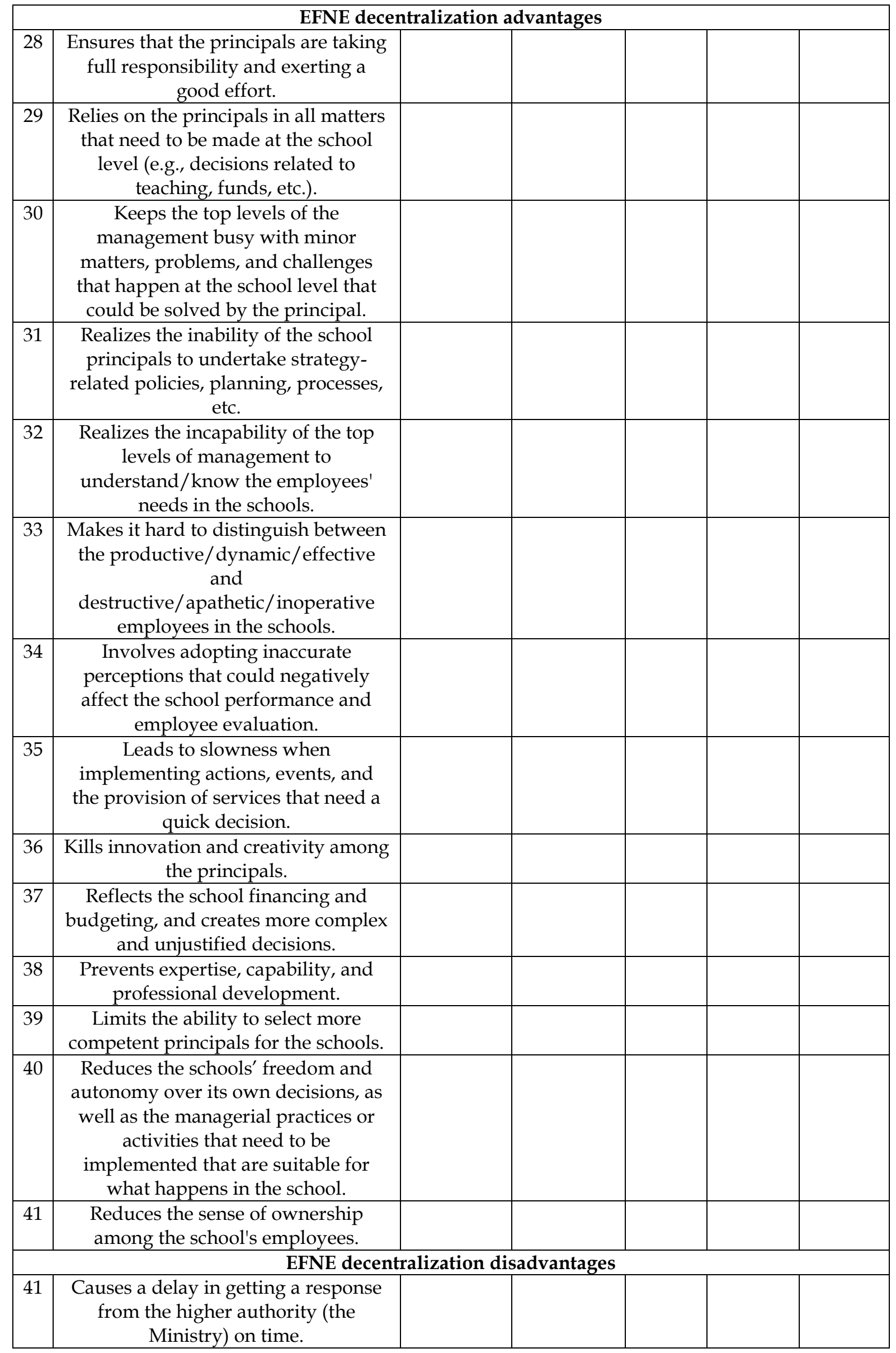




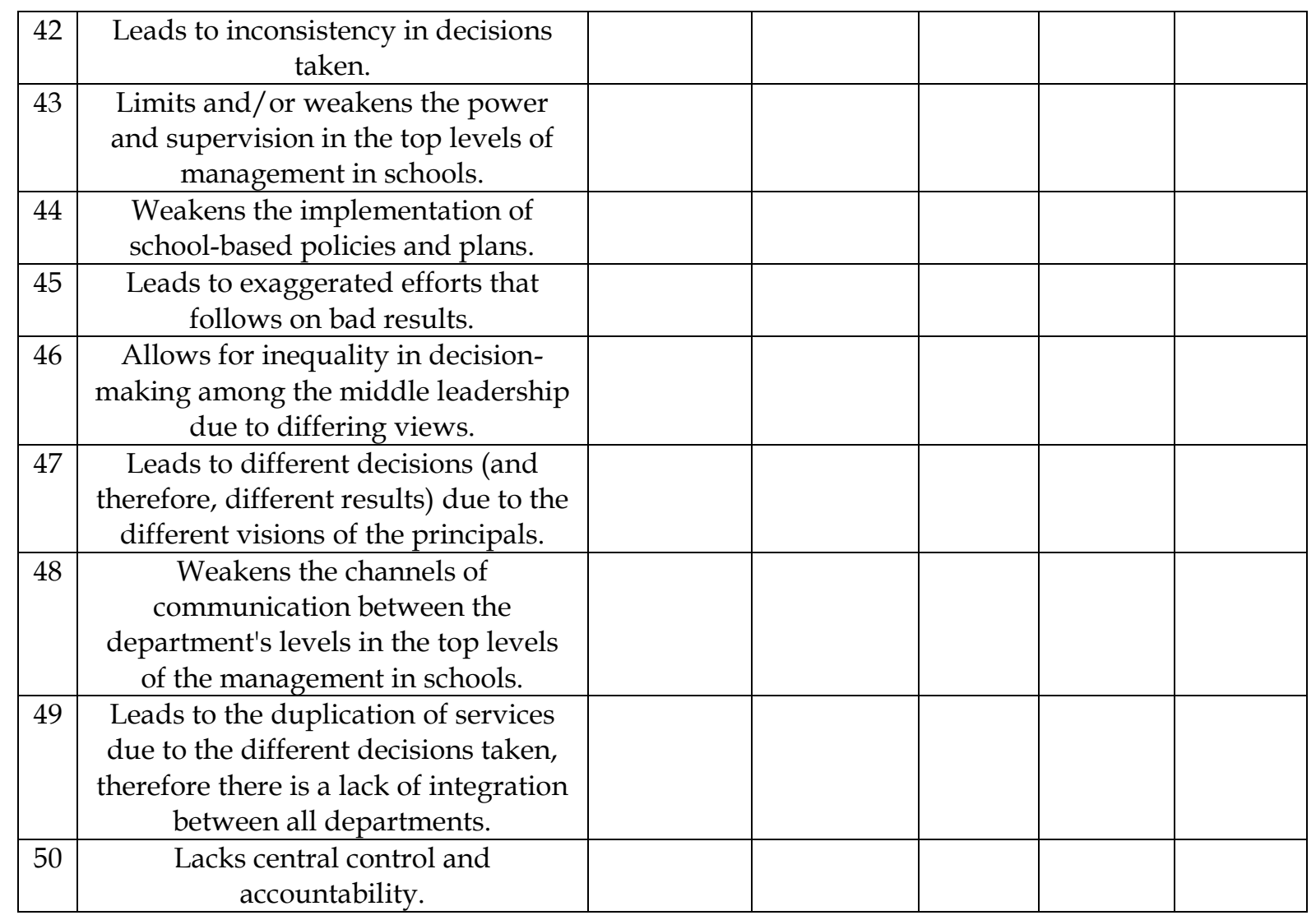

